\title{
Mycobacterial linear plasmids have an invertron-like structure related to other linear replicons in actinomycetes
}

\author{
Mathieu Picardeau and Véronique Vincent
}

Laboratoire de Référence des Mycobactéries, Institut Pasteur, 75724 Paris Cedex 15, France

\author{
Author for correspondence: Véronique Vincent. Tel: +33145688360 . Fax: +33140613118 . \\ e-mail: vvincent@pasteur.fr
}

\begin{abstract}
The authors previously identified large plasmids in Mycobacterium xenopi, $\boldsymbol{M}$. branderi and $M$. celatum which appeared to have a linear topology. This study has confirmed the presence of such linear plasmids in mycobacteria, including $M$. avium, and demonstrated that the ends of these replicons are covalently bound with protein(s), suggesting an invertron-like structure. The termini of one $25 \mathrm{~kb}$ plasmid, designated PCLP, from $M$. celatum were cloned and the first 500 bp of each terminus were sequenced. The termini of this plasmid show the characteristic features of invertrons with terminal inverted repeats of $\mathbf{4 5}$ bp (with imperfect matches) and several palindromic sequences. Moreover, similarity existed in the structure and terminal nucleotide sequence of pCLP and the termini of linear replicons of Streptomyces and Rhodococcus species, indicating a conservation of these linear extrachromosomal elements within the Actinomycetales.
\end{abstract}

Keywords: mycobacteria, actinomycetes, linear plasmids, invertron

\section{INTRODUCTION}

Our understanding of the organization of bacterial genomes has been greatly modified over the past few years. Many reports have revealed a wide variety of bacterial chromosomes. For example, Agrobacterium tumefaciens contains both a linear and a circular chromosome, Rhodobacter sphaeroides has two circular chromosomes, while Streptomyces and Borrelia species have linear chromosomes (Hinnebusch \& Tilly, 1993). Extrachromosomal elements also consist of molecules of both linear and circular topology.

The first bacterial linear plasmid, pSLA2, was isolated in 1979 from Streptomyces rochei (Hayakawa et al., 1979). Among the linear elements, Sakaguchi has defined a class of extrachromosomal elements with inverted repeats at their ends and protein bound to their $5^{\prime}$ ends, termed invertrons (Sakaguchi, 1990). These structural characteristics have been found in some actinomycetes, viruses and bacteriophages, as well as in eukaryotic cells. A second class of bacterial linear plasmids, having covalently closed ends at the termini of the DNA, was reported in the genus Borrelia (Hinnebusch et al., 1990).

Abbreviation: TIR, terminal inverted repeat.

The GenBank accession numbers of the nucleotide sequences of the left and right termini of PCLP are AF044971 and AF044972, respectively.
In a previous study, we demonstrated the presence of extrachromosomal elements in Mycobacterium xenopi, $M$. celatum and $M$. branderi that migrated in pulsedfield gel electrophoresis (PFGE) like linear molecules. The susceptibility of these elements to exonucleases also supported their linear topology and suggested an invertron-like structure (Picardeau \& Vincent, 1997). Therefore, we have undertaken a physical study of the ends of these linear plasmids to determine whether they are linked with proteins and contain inverted repeats. We also studied the relationships of the mycobacterial linear plasmids with those of other actinomycetes.

\section{METHODS}

Mycobacterial strains. The $M$. celatum strains used in this study were clinical isolates kindly provided by W. R. Butler (Centers for Disease Control, Atlanta, USA). As previously described, $M$. celatum strain 4 contains two extrachromosomal elements of about 25 and $320 \mathrm{~kb}$, and $M$. celatum strain 9 contains one extrachromosomal element of $180 \mathrm{~kb}$ (Picardeau \& Vincent, 1997). M. avium strain 951849 was a clinical isolate from our laboratory (Centre National de Référence des Mycobactéries, Institut Pasteur).

PFGE. Mycobacterial isolates were cultivated in Middlebrook 7H9 broth, and cells were embedded in agarose and lysed as previously described (Picardeau et al., 1996). For preparation of non-proteolytically treated plasmids, proteinase $\mathrm{K}$ was 
(a)

PK: $\quad+-+-$

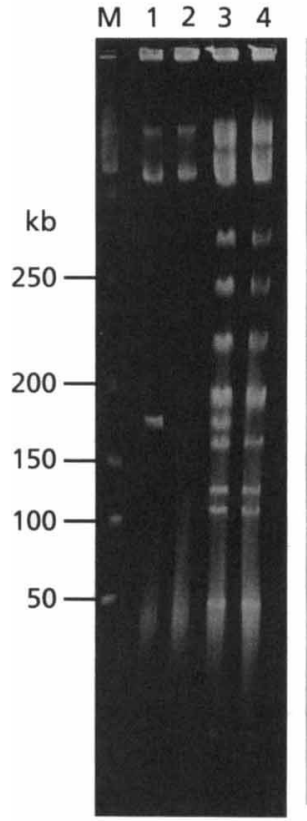

(b)

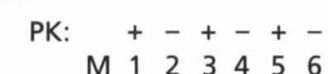

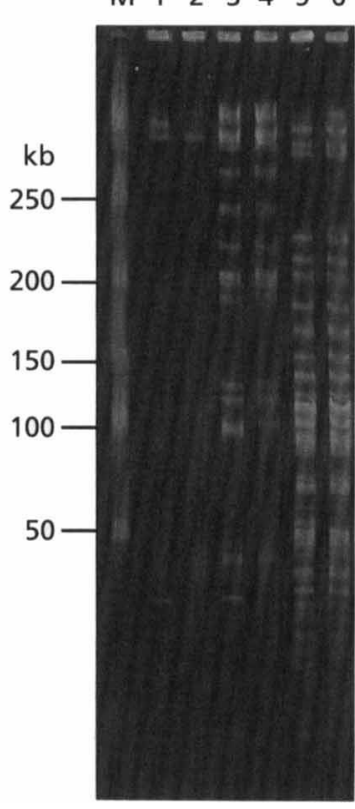

(c) $\mathrm{PK}:+$

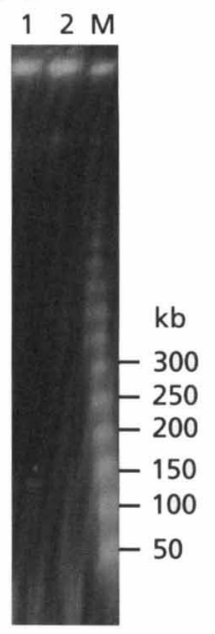

12

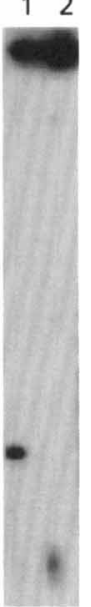

Fig. 1. PFGE of DNA genomic preparations obtained either by the standard isolation procedure, including proteinase $K$ (PK) treatment, or without proteinase K treatment, as indicated. (a) PFGE and Southern blot analysis of $M$. celatum strain 9 performed with the radiolabelled $180 \mathrm{~kb}$ plasmid of the host strain. Lanes 1 and 2, undigested DNA; lanes 3 and 4, DNA digested with Dral. (b) PFGE and Southern blot analysis of $M$. celatum strain 4 performed with the radiolabelled $25 \mathrm{~kb}$ plasmid of the host strain. Lanes 1 and 2, undigested DNA; lanes 3 and 4, DNA digested with Dral; lanes 5 and 6, DNA digested with $X$ bal. (c) PFGE and Southern blot analysis of $M$. avium strain 951849 performed with the radiolabelled $145 \mathrm{~kb}$ plasmid of the host strain. Lanes 1 and 2, undigested DNA. Lanes M, $50 \mathrm{~kb}$ DNA concatemers of the bacteriophage $\lambda$ genome (sizes are indicated in $\mathrm{kb}$ beside the gel).

omitted and plugs were incubated in $1 \%(\mathrm{w} / \mathrm{v}$ ) SDS, $0.05 \mathrm{M}$ EDTA instead of $N$-lauroylsarcosinate, $0.5 \mathrm{M}$ EDTA. For digestion, plugs were extensively washed in TE buffer $(10 \mathrm{mM}$ Tris $/ \mathrm{HCl}, \mathrm{pH} 8 \cdot 0,1 \mathrm{mM}$ EDTA) and incubated with $\mathrm{XbaI}$ or Dral for $2 \mathrm{~h}$ at $37^{\circ} \mathrm{C}$. PFGE was performed by zero-integratedfield electrophoresis (ZIFE; Vysis, Les Ulis, France) using the 8-200 $\mathrm{kb}$ and 8-500 kb ROM cards.

Isolation of linear plasmid DNA. Separation of plasmid from chromosomal DNA was achieved by PFGE of highly concentrated DNA agarose plugs. DNA bands were excised from PFGE agarose gels and the plasmids were recovered from the gel by using a nucleic acid extraction kit (Nucleotrap, Macherey-Nagel). The linear plasmid DNA was eluted with $\mathrm{TE}$ as recommended by the manufacturer.

Southern blotting. DNA bands separated by PFGE, performed as described above, were blotted onto nylon membranes. The membranes were hybridized overnight at $65^{\circ} \mathrm{C}$ in Rapid hybridization buffer (Amersham) with the linear plasmid DNA probe radiolabelled with $\left[\alpha^{-32} \mathrm{P}\right] \mathrm{dCTP}$ using a commercial kit (Megaprime, Amersham). The membranes were then washed as described previously (Picardeau et al., 1996).

Cloning and sequencing of terminal DNA fragments. The $25 \mathrm{~kb}$ linear plasmid DNA of $M$. celatum strain 4, designated pCLP, was digested with $X b a I$. The $X b a I$ was inactivated at $65^{\circ} \mathrm{C}$, and the digested DNA was purified into distilled sterile water and ligated into the HinclI/XbaI sites of pBluescript II $\mathrm{KS}^{+1-}$ (Stratagene). The ligation mixture was transformed into Escherichia coli XL-1 Blue MRF' (Stratagene) by electro- poration (Gene Pulser unit, Bio-Rad). Recombinant colonies were selected on Luria-Bertani solid medium [10 g Bactotryptone $\mathrm{l}^{-1}$ (Difco), $5 \mathrm{~g}$ yeast extract $\mathrm{l}^{-1}, 10 \mathrm{~g} \mathrm{NaCl}^{-1}, \mathrm{pH}$ 7.5] supplemented with $100 \mu \mathrm{g}$ ampicillin $\mathrm{ml}^{-1}, 2 \mathrm{mM}$ IPTG and $0.04 \%$ X-Gal. Recombinant plasmids were isolated by alkaline lysis (Birnboim \& Doly, 1979) or a Qiagen Midi kit. The presence of inserts into the recombinant plasmids was determined by restriction analysis.

The sequences of the double-stranded plasmid DNAs were determined by the dideoxy chain-termination method (Sanger et al., 1977) with universal and reverse primers by using a Taq DyeDeoxy terminator cycle sequencing kit (Applied Biosystems), a model 9600 GeneAmp PCR system (Perkin-Elmer), and a model 373 stretch DNA analysis system (Applied Biosystems). Nucleotide sequences were analysed using the GCG package (University of Wisconsin, Madison, WI, USA) and The DNA Inspector Ile software (Textco, Lebanon, NH, USA).

PCR assays. Amplification reactions were performed in volumes of $50 \mu \mathrm{l}$ containing $1 \times$ Taq polymerase buffer [50 mM Tris/HCl, pH 8.3, $50 \mathrm{mM} \mathrm{KCl,} 1.5 \mathrm{mM} \mathrm{MgCl}_{2}$, $0 \cdot 01 \%(\mathrm{w} / \mathrm{v})$ gelatin], $5 \mu \mathrm{l}$ dimethyl sulfoxide, $200 \mu \mathrm{M}$ of each deoxynucleoside triphosphate, $1 \mu \mathrm{M}$ of each primer, and $2 \mathrm{U}$ Taq polymerase (Perkin-Elmer) for 38 cycles: $1 \mathrm{~min}$ at $95^{\circ} \mathrm{C}$, $1 \mathrm{~min}$ at $55^{\circ} \mathrm{C}$, and $1 \mathrm{~min}$ at $72^{\circ} \mathrm{C}$, followed by a $10 \mathrm{~min}$ extension at $72^{\circ} \mathrm{C}$.

We selected primers Com (5'-CCC CCC CCC CGGCTT CGC CG-3'), V3 (5'-AAG AAA TAC AGA TAC CCG CC- $\left.3^{\prime}\right)$, 
Ec4.2 (5'-ATT TTT CGT GAT GCT TGC CG-3'), L2 (5'GCA CAA CGA TTT AGA GAC GC-3') and L3B ( $5^{\prime}$-GTC AGG TTG CTC CAC GCT GG-3') from the nucleotide sequences of the linear plasmid pCLP (see Fig. 2 for the locations of primers). Primers were tested on crude DNA extract of $M$. celatum strain 4 and on the two isolated plasmids, of $25 \mathrm{~kb}$ and $320 \mathrm{~kb}$. The amplified products (the $403 \mathrm{bp}$ product of Com/V3, the 333 bp product of Com/Ec4.2 and the $246 \mathrm{bp}$ product of L2/L3B) were cloned into pGEM$\mathrm{T}$ (Promega) as recommended by the manufacturer and the recombinant plasmids were isolated and sequenced as described above.

\section{RESULTS}

\section{Association of protein(s) with the DNA of the linear plasmids}

To investigate whether the plasmids contained a covalently bound protein, proteinase $\mathrm{K}$ was omitted from the lysis treatment of the cells during the preparation of the plugs. The objective was to preserve the putative terminal protein, which could be expected to retard the linear plasmid DNA during electrophoresis as shown for invertrons (Hirochika \& Sakaguchi, 1982; Kinashi \& Shimaji-Murayama, 1991). The result is shown in Fig. 1. The preparation of mycobacterial genomic DNA without proteinase $\mathrm{K}$ did not allow the extrachromosomal elements to enter the gel (Fig. 1a, b, c, lanes 2). Proteinase-K-treated and -untreated DNA samples were also electrophoresed after digestion with
DraI and XbaI. The restriction patterns of the chromosomal DNAs were identical in proteinase-K-treated and -untreated DNAs, suggesting that the chromosomal DNAs were released and migrated into the gel in the absence of proteinase $\mathrm{K}$ treatment (Fig. 1a, lanes 3 and 4; Fig. 1b, lanes 3-6). Southern blot analysis following PFGE of undigested DNA probed with the host plasmids (the $180 \mathrm{~kb}$ plasmid detected in $M$. celatum strain 9, the $25 \mathrm{~kb}$ plasmid detected in $M$. celatum strain 4 , and the $145 \mathrm{~kb}$ plasmid in M. avium strain 951849 , respectively) revealed that the extrachromosomal elements remained trapped in the wells (Fig. 1a, b, c, lanes 2). The same results were obtained for all the linear plasmids tested in other species including M. xenopi and M. branderi (data not shown).

\section{Cross-hybridization of the $\mathbf{2 5} \mathbf{~ k b}$ linear plasmid with genomic DNA}

Southern blot analysis following PFGE of DraI- and $X$ baI-digested DNA probed with the plasmids revealed that the extrachromosomal elements did not crosshybridize with any DNA fragments of the chromosome of $M$. celatum strain 9 (Fig. 1a, lane 4). Our data also demonstrated that both plasmids of $M$. celatum strains 4 and 9 used as probes were not digested with DraI (Fig. 1). One element, the $25 \mathrm{~kb}$ plasmid from $M$. celatum strain 4, hybridized with the larger plasmid (Fig. 1b, lane 1). The size of this plasmid was estimated to be $320 \mathrm{~kb}$ by comparison with linear standards using migration

(a)
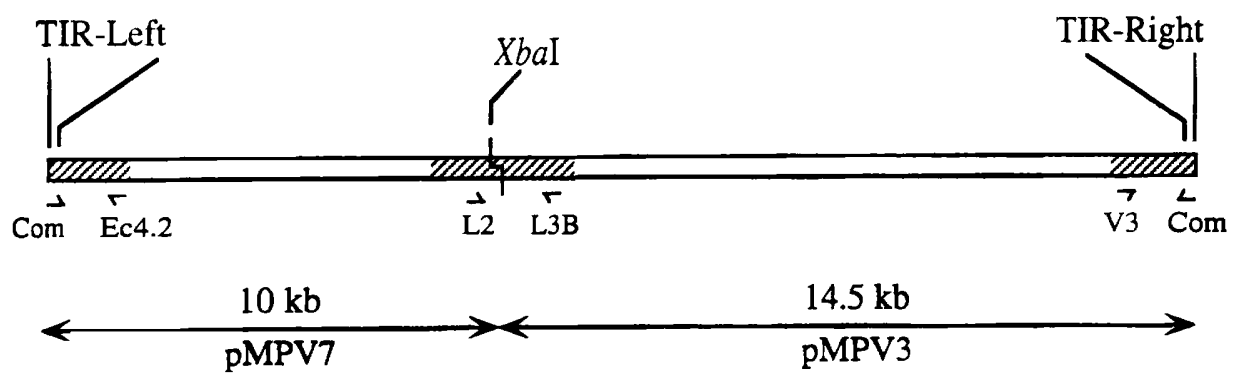

(b)

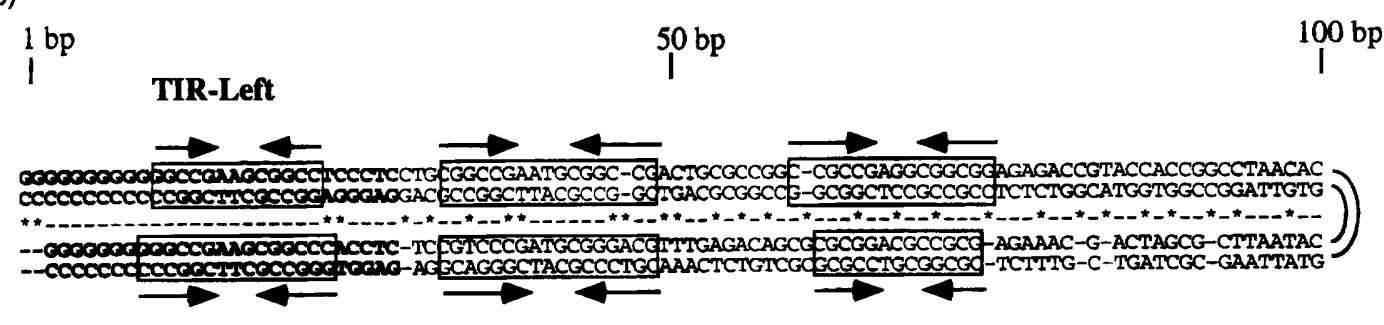

TIR-Right

Fig. 2. Cloning and sequence analysis of plasmid pCLP of $M$. celatum strain 4 . (a) The inserts of $10 \mathrm{~kb}$ and $14.5 \mathrm{~kb}$ of recombinant plasmids pMPV7 and pMPV3, respectively, corresponding to the whole length of pCLP. Regions which have been sequenced are indicated by hatched boxes. The $X$ bal site, terminal inverted repeats (TIRs) and primers used for PCR analysis are indicated. (b) Alignment of the first 100 bp of the ends of pCLP showing the nucleotide sequences of the left and right termini. Identical $(-)$ and different $\left(^{*}\right)$ nucleotides are indicated. TIR sequences are in bold and palindromic sequences are boxed, with their short inverted repeats indicated by arrows. 
conditions which resolved higher molecular mass fragments (Picardeau \& Vincent, 1997). The plasmid estimated at $25 \mathrm{~kb}$ was designated as PCLP, while the other, of $320 \mathrm{~kb}$, was designated pLLP. Interestingly, we found hybridizations with several restriction fragments larger than the $25 \mathrm{~kb}$ plasmid (Fig. 1b, lanes 3-6). The presence of two hybridization signals with proteinase-K-treated and -untreated DNA digested with DraI (Fig. 1b, lanes 3 and 4) suggest either the homology of pCLP with internal fragments of pLLP and/or cross-hybridization with the chromosomal DNA. Southern blot analysis also suggested that $\mathrm{PCLP}$ was restricted by $\mathrm{XbaI}$ and that the two restriction fragments obtained, corresponding to the two hybridization signals in the lower part of the blot, were retarded in PFGE by omission of proteinase $\mathrm{K}$ treatment (Fig. 1b, lane 5).

\section{Characteristic features of the termini of pCLP}

In comparison with linear replicons belonging to the genus Streptomyces, we hypothesized that free ends of mycobacterial linear plasmids, after proteinase $\mathrm{K}$ treatment, were blunted. For determining the DNA nucleotide sequence of the terminal fragments, pCLP was isolated and digested with $\mathrm{Xba \textrm {I }}$. As Southern blot analysis after $X b a \mathrm{I}$ digestion was consistent with the presence of a single $X b a I$ restriction site within pCLP, both restriction fragments could include the termini of this plasmid. The XbaI fragments were cloned into a Bluescript vector restricted with $X b a \mathrm{I}$ and $H$ inclI. Thus, ligation of $X b a \mathrm{I}$ fragments could only occur with the $X b a \mathrm{I}$ end of the vector and its opposite blunt end produced by the HincII cut. Among the transformants isolated, the restriction analysis of the cloned inserts showed two large fragments, of $10 \mathrm{~kb}$ and $14.5 \mathrm{~kb}$, within the recombinant plasmids. These recombinant plasmids, designated pMPV7 and pMPV3, were selected for sequencing. The nucleotide sequence of $500 \mathrm{bp}$ at each extremity of both inserts was determined (Fig. 2a).

Sequence analysis of the cloned end fragments revealed a high homology between the two terminal nucleotide sequences. The termini of pCLP contained $29 \mathrm{bp}$ imperfect inverted repeats ( $93 \%$ base identity). This similarity could be extended for a further $16 \mathrm{bp}$ at somewhat lower levels of identity ( $80 \%$ base identity). Surprisingly, we found that the first $10 \mathrm{bp}$ of termini contain only guanines (Fig. 2b). Palindromic sequences, consisting of a cluster of two short inverted repeats, were located in the first $100 \mathrm{bp}$. Only a few other palindromes were found outside the first $100 \mathrm{bp}$ of the termini. Although the terminal nucleotide sequences were not completely homologous to each other, the palindromic sequences had the same locations (Fig. 2b).

Due to the cloning strategy employed, the possible loss of a small internal $\mathrm{X} b a \mathrm{I}$ fragment could not be excluded. Thus, we selected primers L $3 B$ and L2 from the inserts of recombinant plasmids pMPV3 and pMPV7, respectively, to check that the whole length of pCLP had been cloned. Moreover, to detect any rearrangement during

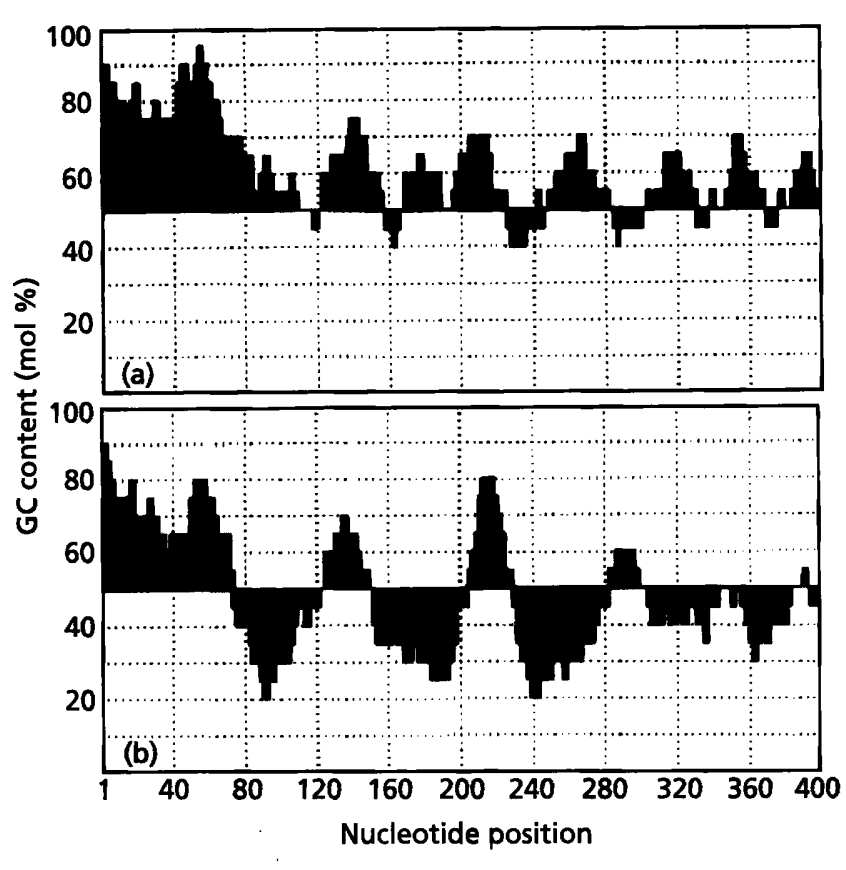

Fig. 3. Base composition analysis of the first $400 \mathrm{bp}$ of the terminal DNA fragments of plasmid pCLP of $M$. celatum strain 4. (a) Nucleotide sequence of the left terminus of PCLP corresponding to the insert of recombinant plasmid pMPV7. (b) Nucleotide sequence of the right terminus of PCLP corresponding to the insert of recombinant plasmid pMPV3.

the cloning procedures, we synthesized primers based on the known sequences: Com, corresponding to terminal nucleotide sequences shared by the two inserts; V3, from the pMPV3 insert; and Ec4.2 using the pMPV7 insert sequence (Fig. 2). PCR results on crude DNA extract of $M$. celatum strain 4 using primer couples $\mathrm{Com} / \mathrm{V} 3$, Com/Ec4.2 and L2/L3B were consistent with the expected size. The sequence analysis of these PCR products revealed no sequence rearrangements (data not shown). Furthermore, preparative PFGE was used to isolate the 25 and the $320 \mathrm{~kb}$ plasmids, which were subsequently purified and used for PCR analysis. In both plasmids, we obtained the same results with the three primer couples as with the total genomic DNA as template (data not shown).

We also studied the base composition of the first $400 \mathrm{bp}$ of the two terminal fragments. The first $60 \mathrm{bp}$ of the termini had a high GC content. The mean GC content was $62 \mathrm{~mol} \%$ in the left arm of pCLP and $49 \mathrm{~mol} \%$ in the right terminal fragment. Within the right terminal sequence we found three regions of low GC content (less than $30 \%$ ), alternating with regions of high GC content. Within the left terminal fragment, except for the first $60 \mathrm{bp}$, the variations in GC content were significantly less pronounced (Fig. 3).

Comparison of the DNA sequences of pCLP, comprising the terminal fragments and one internal region spanning both inserts (Fig. 2a), with the EMBL and GenBank 


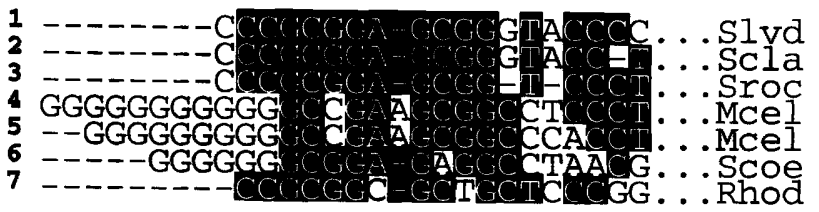

Fig. 4. Terminal nucleotide sequences of linear plasmids from actinomycetes. 1, SLP2 from S. lividans (Chen et al., 1993); 2, pSCL from S. clavuligerus (Wu \& Roy, 1993); 3, pSLA2 from $S$. rochei (Hirochika et al., 1984); 4, left arm of pCLP from $M$. celatum (this study); 5 , right arm of PCLP from $M$. celatum (this study); 6, SCP1 from S. coelicolor (Kinashi et al., 1991); 7, pHG207 from Rhodococcus sp. (Kalkus et al., 1993). Nucleotide sequences identical in at least four sequences are shown on a black background.

databases revealed no significant homologies (data not shown). However, when the terminal nucleotide sequences of pCLP were compared with those of previously known sequences of linear plasmids from actinomycetes, homology was observed (Fig. 4). The first $10 \mathrm{bp}$ of all the termini were quite similar, with a high GC content: only one adenine or one thymine was present (Fig. 4). Interestingly, the six terminal bases of SCP1 from $S$. coelicolor were all guanines.

\section{DISCUSSION}

The linearity of some plasmids in mycobacteria suggested by electrophoretic mobility, nuclease treatment and hybridization experiments (Picardeau \& Vincent, 1997) has been confirmed in this study. The mycobacterial linear plasmids characterized in this study have common features with those of Streptomyces and $R$ hodococcus and with other linear replicons designated as invertrons. They contain terminal inverted repeats (TIRs) with proteins linked to their ends (Sakaguchi, 1990).

\section{Structure of mycobacterial linear plasmids}

In this study, we demonstrated that proteins were covalently bound to the mycobacterial linear plasmids. These proteins were removed after proteinase $\mathrm{K}$ treatment. On the basis of the retardation of the terminal fragments of plasmids during PFGE and of their susceptibility to exonuclease III (Picardeau \& Vincent, 1997), the structure of the mycobacterial linear plasmids can be assigned to the class of invertron (Sakaguchi, 1990). Taking into account that all invertrons described in prokaroytes and eukaryotes have proteins covalently attached at their $5^{\prime}$ ends (Sakaguchi, 1990), one may assume that this is also the case for the mycobacterial linear plasmids. Further investigation will include the characterization of the DNA-protein complex.

The fact that the termini of pCLP can be ligated to the blunt ends of a cloning vector indicates that these termini are blunt. The existence of TIRs confirmed the invertron-like structure. In actinomycetes, the size of these TIRs is quite variable, ranging from $44 \mathrm{bp}$ in SLP2 to 9500 bp in pPZG101 (Chen et al., 1993; Gravius et al., 1994). There is no correlation between plasmid size and the length of the TIR sequence (see Table 1). Analysis of the integration of sex factor SCP1 of Streptomyces coelicolor into the chromosome showed that the free ends of SCP1 had been lost, suggesting a role of these TIRs in the integration of linear replicons similar to that of the TIRs of transposons (Hanafusa \& Kinashi, 1992). Thus, the presence of TIR sequences within mycobacterial linear plasmids raises the possibility of their integration into the chromosome. However, we did not find any evidence of such events.

The palindromic sequences that we identified at the plasmid ends are also a characteristic feature of linear replicons. Interestingly, the sequence alignment of termini of other actinomycete linear plasmids (Fig. 4) showed a highly conserved region within the first $20 \mathrm{bp}$ which corresponds to the first palindrome detected in mycobacterial plasmids (Fig. 2). In pCLP palindromes, hairpin sequences are often trinucleotides. These trinucleotides are GNA, which has been shown to form a stable single-residue loop closed by $\mathrm{G}$ and $\mathrm{A}$, constituting a so-called sheared pairing (Chou et al., 1997). For linear replicons of streptomycetes, they are thought to be potential hairpins required for the replication of the termini (Chen, 1996). The left arm of pCLP is noticeable because of its region of very low GC content. AT-rich regions were also observed in the terminal sequences of pHG207 from Rbodococcus sp. (Kalkus et al., 1993). Such an AT-rich region might facilitate strand separation at the initial stage of replication termini and/or could be the evidence of a foreign origin of the mycobacterial linear plasmids from micro-organisms with a low GC content.

Hybridization experiments with pCLP as a probe (Fig. 1), and PCR analysis of the termini and of an internal region of $\mathrm{pCLP}$, suggest the presence of $\mathrm{pCLP}$ within the $320 \mathrm{~kb}$ plasmid of $M$. celatum strain 4 in at least one copy.

PCR analysis confirmed that the whole length of the plasmid has been cloned. Sequence analysis and subcloning experiments can now be undertaken for further investigation of the replication mechanisms and specially for the identification of a putative DNA polymerase gene, detected in almost all linear plasmids sequenced to date (Chang et al., 1996; Wu \& Roy, 1993).

\section{Distribution of linear plasmids in Actinomycetales}

Initially, mycobacterial linear plasmids were found in $M$. xenopi, M. celatum and M. branderi. An investigation of possible hosts for linear replicons has allowed the detection of other linear plasmids in M. avium.

In Table 1, we report all the linear replicons described to date within the actinomycetes except derivatives of pSLA2 and other plasmids whose structures and 
Table 1. Distribution of linear plasmids in Actinomycetales

\begin{tabular}{|c|c|c|c|c|c|c|c|}
\hline Species* & $\begin{array}{c}\text { Plasmid } \\
\text { designation }\end{array}$ & $\begin{array}{l}\text { Length } \\
\text { (kb) }\end{array}$ & $\begin{array}{l}\text { Blunt ends } \\
\text { and/or } \\
\text { terminal } \\
\text { proteins }\end{array}$ & $\begin{array}{l}\text { TIR } \\
\text { (bp) }\end{array}$ & $\begin{array}{l}\text { Conjugative } \\
\text { transfer }\end{array}$ & Functions/genes carried & References \\
\hline M. celatum $4 \dagger$ & pCLP & 25 & yes & 45 & ND & ND & This study \\
\hline R. fascians & pFID188 & 200 & ND & ND & yes & $\begin{array}{l}\text { Development of } \\
\text { fasciation in plants }\end{array}$ & $\begin{array}{l}\text { Crespi et al. (1992, } \\
\text { 1994) }\end{array}$ \\
\hline R. erythropolis & pBD2 & 208 & ND & ND & yes & $\begin{array}{l}\text { Degradation of } \\
\text { isopropylbenzene and } \\
\text { co-oxidation of } \\
\text { trichloroethene }\end{array}$ & $\begin{array}{c}\text { Dabrock et al. (1994); } \\
\text { Kebeler et al. (1996) }\end{array}$ \\
\hline R. opacus $\ddagger$ & pHG207 & 225 & yes & 583 & yes & Hydrogen autotrophy & $\begin{array}{l}\text { Kalkus et al. (1993, } \\
\text { 1990) }\end{array}$ \\
\hline R. erythropolis & pTA421 & 500 & ND & ND & ND & Biphenyl degradation & Kosono et al. (1997) \\
\hline R. globerulus & pSP6/pLP6 & $350 / 650$ & ND & ND & ND & Biphenyl degradation & Kosono et al. (1997) \\
\hline S. lividans & SLP2 & 50 & yes & 44 & yes & ND & Chen et al. (1993) \\
\hline S. lividans & pBL1S & 43 & yes & ND & yes & ND & Zotchev et al. (1992) \\
\hline S. clavuligerus & pSCL1 & 12 & yes & 900 & ND & Regulatory proteins & $\begin{array}{l}\text { Keen et al. (1988); } \\
\text { Wu \& Roy }(1993)\end{array}$ \\
\hline S. rochei & pSLA2 & 17 & yes & 614 & ND & $\begin{array}{l}\text { Lankacidin group } \\
\text { antibiotics }\end{array}$ & $\begin{array}{l}\text { Hirochika et al. } \\
\text { (1984); Hayakawa } \\
\text { et al. (1979) }\end{array}$ \\
\hline S. rimosus & pSRM & 43 & yes & ND & ND & ND & $\begin{array}{l}\text { Chardon-Loriaux et } \\
\text { al. (1986) }\end{array}$ \\
\hline S. ambofaciens & pSAM $\|$ & 80 & ND & ND & ND & ND & $\begin{array}{l}\text { Leblond et al. (1990, } \\
\text { 1996) }\end{array}$ \\
\hline S. avermitilis & $\mathrm{pSA} 1 / \mathrm{pSA} 2$ & $100 / 250$ & ND & ND & ND & ND & Evans et al. (1994) \\
\hline S. rimosus & pPZG101 & 387 & ND & 9500 & ND & ND & Gravius et al. (1994) \\
\hline S. coelicolor & SCP1 & 350 & yes & 7000 & yes & $\begin{array}{l}\text { Methylenomycin; spore } \\
\text { formation }\end{array}$ & $\begin{array}{l}\text { Kinashi (1994); } \\
\text { Kinashi } \text { et al. (1987); } \\
\text { Kinashi \& Shimaji- } \\
\text { Murayama (1991) }\end{array}$ \\
\hline S. lasaliensis & $\mathrm{pKSL}$ & 520 & ND & ND & ND & $\begin{array}{l}\text { Lasalocid and } \\
\text { echinomycin }\end{array}$ & Kinashi (1994) \\
\hline
\end{tabular}

ND, Not determined.

*M., Mycobacterium; R., Rbodococcus, S., Streptomyces.

† Other linear plasmids have been identified in M. avium, M. xenopi, M. celatum and M. branderi (Picardeau \& Vincent, 1997; this study). $\ddagger$ Formerly Nocardia opaca.

\$pBL1 was isolated from a plasmidless strain after its mating with S. bambergiensis S712 harbouring the $640 \mathrm{~kb}$ plasmid PSB1.

$\|$ pSAM1 is found as either a linear or a circular molecule.

functions have not been studied (Kinashi, 1994). In studies where the existence of terminal proteins and/or TIR sequences has not been described, the linearity of the molecules was demonstrated by their electrophoretic behaviour, the restriction analysis of the plasmid (in this case the sum of restriction fragments was in agreement with the molecular mass obtained by PFGE), by their susceptibility to exonucleases treatment or by electron microscopy (Chardon-Loriaux et al., 1986; Hayakawa et al., 1979; Kosono et al., 1997). We can assume that all these linear replicons have an invertron-like structure.

Within the genera Streptomyces and Rhodococcus, belonging, like the genus Mycobacterium, to the order
Actinomycetales (Stackebrandt et al., 1997), several linear plasmids as carriers of genetic information have been described (Table 1). The genus Rhodococcus contains micro-organisms that exhibit broad metabolic diversity (Finnerty, 1992). Most of these metabolic properties are encoded on circular or linear plasmids (Dabrock et al., 1994; Finnerty, 1992; Kalkus et al., 1993; Kebeler et al., 1996). The species Nocardia opaca, where the pHG207 linear plasmid was identified (Kalkus et al., 1990), has been renamed as a Rhodococcus species. The genus Rhodococcus also includes a plantpathogenic species, $R$. fascians, harbouring a plasmid responsible for development of fasciation in plants (Crespi et al., 1992, 1994) (Table 1). The genus Strepto- 
myces comprises many antibiotic-producing species, accounting for over $70 \%$ of naturally occurring antibiotics (Berdy, 1980). Most of the antibiotic biosynthesis genes have been found to be chromosomal. However, some of these genes are located on linear plasmids (Hayakawa et al., 1979; Kinashi, 1994; Kinashi et al., 1987).

Streptomyces, Rhodococcus and Mycobacterium spp. contain plasmids of both circular and linear topology (Kinashi, 1994; Zotchev et al., 1992). However, it is interesting that while the chromosomes of both Streptomyces and Rhodocccus species appear linear (Crespi et al., 1992; Lin et al., 1993), the chromosome of the Mycobacterium species investigated so far is circular (Philipp et al., 1996; Picardeau \& Vincent, 1997). The linearity of the chromosome of streptomycetes and nocardioforms could derive from the integration of linear plasmids (Gravius et al., 1994; Lin et al., 1993). Among prokaryotes, only a few phages have the same structure as the Streptomyces linear plasmids (Hinnebusch \& Tilly, 1993). As suggested by Chang et al. (1996), Streptomyces linear plasmids may occupy an evolutionarily intermediate position between circular plasmids and linear phage replicons. Little information is available on extrachromosomal elements of other genera belonging to the order Actinomycetales. The study of their basic genetics has been relatively neglected, and thus it will not be surprising if linear plasmids are identified in other actinomycetes.

In actinomycetes, almost all the extensively studied linear replicons have been found to be transmissible plasmids (Table 1). These plasmids may have played an important role in the evolution of the catabolic pathway for some compounds and for the dissemination of antibiotic biosynthesis genes. Some of these plasmids can integrate into the chromosome (Gravius et al., 1994; Kinashi et al., 1992). To date, it is unknown whether mycobacterial plasmids, including both circular and linear molecules, are capable of conjugative transfer. It is relevant that mycobacteria are not competent for transformation and their cell walls are considered as a barricr. However, there is evidence that recombination occurs in nature. Recently, intrageneric transfer of mercury resistance between Mycobacterium fortuitum and M. smegmatis has been observed in mating experiments (Gavigan et al., 1997). However, the conjugational fertility was not attributed to any identified plasmids. Sequence homologies were found between circular plasmids from rapidly growing and slowgrowing mycobacteria (Gavigan et al., 1997) and between plasmids from Rhodococcus species and plasmid pAL5000 from M. fortuitum (DeMot et al., 1997; Kulakov et al., 1997). Further evidence of genetic exchanges is also supported by the existence of homologous insertion sequences within mycobacteria and related micro-organisms (Kato et al., 1994; Picardeau et al., 1997). Moreover, conjugative transfer of a shuttle plasmid from E. coli to M. smegmatis has been reported (Lazrak et al., 1990). Although plasmids are suggested to play a role in genetic exchanges, no experimental evidence has been obtained in mycobacteria. It could be of interest to investigate the conjugative ability of the mycobacterial linear plasmids. Genctic flux may have occurred between members of these genera, which are common throughout nature.

Further studies of mycobacterial linear plasmids will allow the devclopment of new genetic tools, the utilization of these plasmids as epidemiological markers and a better understanding of genetic exchange in actinomycetes.

\section{ACKNOWLEDGEMENTS}

We thank C. Chen and I. Saint Girons for interest and helpful advice, and J. Tricas for critical reading of the manuscript. M.P. is the recipient of a fellowship from Fondation Roux, Institut Pasteur.

\section{REFERENCES}

Berdy, J. (1980). Recent advances in and prospects for antibiotic research. Process Biochem 15, 28-35.

Birnboim, H. C. \& Doly, J. (1979). A rapid alkaline extraction procedure for screening recombinant plasmid DNA. Nucleic Acids Res 7, 1513-1523.

Chang, P. C., Kim, E. S. \& Cohen, S. N. (1996). Streptomyces linear plasmids that contain a phage-like, centrally located, replication origin. Mol Microbiol 22, 789-800.

Chardon-Loriaux, I., Charpentier, M. \& Percheron, F. (1986). Isolation and characterization of a linear plasmid from Streptomyces rimosus. FEMS Microbiol Lett 35, 151-1.55.

Chen, C. W. (1996). Complications and implications of linear bacterial chromosomes. Trends Genet 12, 192-196.

Chen, C. W., Yu, T. W., Lin, Y. S., Kieser, H. M. \& Hopwood, D. A. (1993). The conjugative plasmid SLP2 of Streptomyces lividans is a $50 \mathrm{~kb}$ linear molecule. Mol Microbiol 7, 925-932.

Chou, S. H., Zhu, L. \& Reid, B. R. (1997). Sheared purine pairing in biology. J Mol Biol 267, 1055-1067.

Crespi, M., Messens, E., Caplan, A. B., vanMontagu, M. \& Desomer, J. (1992). Fasciation induction by the phytopathogen $R$ bodococcus fascians depends upon a linear plasmid encoding a cytokinin synthase gene. EMBO J 11, 795-804.

Crespi, M., Vereecke, D., Temmerman, W., vanMontagu, M. \& Desomer, J. (1994). The fas operon of Rhodococcus fascians encodes new genes required for efficient fasciation of host plants. J Bacteriol 176, 2492-2501.

Dabrock, B., Kebeler, M., Averhoff, B. \& Gottschalk, G. (1994). Identification and characterization of a transmissible linear plasmid from Rhodococcus erythropolis BD2 that encodes isopropylbenzene and trichloroethene catabolism. Appl Environ Microbiol 60, 853-860.

DeMot, R., Nagy, I., DeSchrijver, A., Pattanapipitpaisal, P., Schoofs, G. \& Vanderleyden, J. (1997). Structural analysis of the $6 \mathrm{~kb}$ cryptic plasmid pFAJ2600 from Rhodococcus erythropolis NI86/21 and construction of Escherichia coli-Rhodococcus shuttle vectors. Microbiology 143, 3137-3147.

Evans, M., Kaczmarek, F. S., StutzmanEngwall, K. \& Dyson, P. (1994). Characterization of a Streptomyces lividans-type sitespecific DNA modification system in the avermectin producer Streptomyces avermitilis permits investigation of two novel giant linear plasmids, pSA1 and pSA2. Microbiology 140, 1367-1371. 
Finnerty, W. R. (1992). The biology and genetics of the genus Rhodococcus. Annu Rev Microbiol 46, 193-218.

Gavigan, J. A., Ainsa, J. A., Pérez, E., Otal, I. \& Martin, C. (1997). Isolation by genetic labeling of a new mycobacterial plasmid, pJAZ38, from Mycobacterium fortuitum. J Bacteriol 179, 4115-4122.

Gravius, B., Glocker, D., Pigac, J., Pandza, K., Hranueli, D. \& Cullum, J. (1994). The $387 \mathrm{~kb}$ linear plasmid pPZG101 of Streptomyces rimosus and its interactions with the chromosome. Microbiology 140, 2271-2277.

Hanafusa, T. \& Kinashi, H. (1992). The structure of an integrated copy of the giant linear plasmid SCP1 in the chromosome of Streptomyces coelicolor 2612. Mol Gen Genet 231, 363-368.

Hayakawa, T., Tanaka, T., Sakaguchi, K., Otake, N. \& Yonehara, H. (1979). A linear plasmid-like DNA in Streptomyces sp. producing lankacidin group antibiotics. J Gen Appl Microbiol 25, 255-260.

Hinnebusch, J. \& Tilly, K. (1993). Linear plasmids and chromosomes in bacteria. Mol Microbiol 10, 917-922.

Hinnebusch, J., Bergström, S. \& Barbour, A. G. (1990). Cloning and sequence analysis of linear plasmid telomeres of the bacterium Borrelia burgdorferi. Mol Microbiol 4, 811-820.

Hirochika, H. \& Sakaguchi, K. (1982). Analysis of linear plasmids isolated from Streptomyces: association of protein with the ends of the plasmid DNA. Plasmid 7, 59-65.

Hirochika, H., Nakamura, K. \& Sakaguchi, K. (1984). A linear DNA plasmid from Streptomyces rochei with an inverted terminal repetition of 614 base pairs. EMBO J 3, 761-766.

Kalkus, J., Reh, M. \& Schlegel, H. G. (1990). Hydrogen autotrophy of Nocardia opaca strains is encoded by linear megaplasmids. $J$ Gen Microbiol 136, 1145-1151.

Kalkus, J., Dörrie, C., Fischer, D., Reh, M. \& Schlegel, H. G. (1993). The giant linear plasmid pHG207 from Rbodococcus sp. encoding hydrogen autotrophy: characterization of the plasmid and its termini. J Gen Microbiol 139, 2055-2065.

Kato, K., Ohtsuki, K., Mitsuda, H., Yomo, T., Negoro, S. \& Urabe, I. (1994). Insertion sequence IS6100 on plasmid pOAD2, which degrades nylon oligomers. J Bacteriol 176, 1197-1200.

Kebeler, M., Dabbs, E. R., Averhoff, B. \& Gottschalk, G. (1996). Studies on the isopropylbenzene 2,3-dioxygenase and the 3isopropylcatechol 2,3-dioxygenase genes encoded by the linear plasmid of Rhodococcus erythropolis BD2. Microbiology 142, 3241-3251.

Keen, C. L., Mendelovitz, S., Cohen, G., Aharonowitz, Y. \& Roy, K. L. (1988). Isolation and characterization of a linear DNA plasmid from Streptomyces clavuligerus. Mol Gen Genet 212, 172-176.

Kinashi, H. (1994). Linear plasmids from Actinomycetes. Actinomycetologica 8, 87-96.

Kinashi, H. \& Shimaji-Murayama, M. (1991). Physical characterization of SCP1, a giant linear plasmid from Streptomyces coelicolor. J Bacteriol 173, 1523-1529.

Kinashi, H., Shimaji, M. \& Sakai, A. (1987). Giant linear plasmids in Streptomyces which code for antibiotic biosynthesis genes. Nature 328, 454-456.

Kinashi, H., Shimaji-Murayama, M. \& Hanafusa, T. (1992). Integration of SCP1, a giant linear plasmid, into the Streptomyces coelicolor chromosome. Gene 115, 35-41.
Kosono, S., Maeda, M., Fuji, F., Arai, H. \& Kudo, T. (1997). Three of the seven $b p b C$ genes of Rhodoccoccus erythropolis TA421, isolated from a termite ecosystem, are located on an indigenous plasmid associated with biphenyl degradation. Appl Environ Microbiol 63, 3282-3285.

Kulakov, L. A., Larkin, M. J. \& Kulakova, A. N. (1997). Cryptic plasmid pKA22 isolated from the naphthalene degrading derivative of $R$ hodococcus rhodochrous NCIMB 13064. Plasmid 38, $61-69$.

Lazrak, R., Clavel-Sérés, S., David, H. L. \& Roulland-Dussoix, D. (1990). Conjugative transfer of a shuttle plasmid for Escherichia coli to Mycobacterium smegmatis. FEMS Microbiol Lett 69, 135-138.

Leblond, P., Francou, F. X., Simonet, J. M. \& Decaris, B. (1990). Pulsed-field gel electrophoresis analysis of the genome of Streptomyces ambofaciens strains. FEMS Microbiol Lett 72, 79-88.

Leblond, P., Fischer, G., Francou, F. X., Berger, F., Guérineau, M. \& Decaris, B. (1996). The unstable region of Streptomyces ambofaciens includes $210 \mathrm{~kb}$ terminal inverted repeats flanking the extremities of the linear chromosomal DNA. Mol Microbiol 19, 261-271.

Lin, Y. S., Kieser, H. M., Hopwood, D. A. \& Chen, C. W. (1993). The chromosomal DNA of Streptomyces lividans 66 is linear. Mol Microbiol 10, 923-933.

Philipp, W. J., Poulet, S., Eiglmeier, K. \& 7 other authors (1996). An integrated map of the genome of the tubercle bacillus, Mycobacterium tuberculosis $\mathrm{H} 37 \mathrm{Rv}$, and comparison with $\mathrm{Myco}$ bacterium leprae. Proc Natl Acad Sci USA 93, 3132-3137.

Picardeau, M. \& Vincent, V. (1997). Characterization of large linear plasmids in mycobacteria. J Bacteriol 179, 2753-2756.

Picardeau, M., Varnerot, A., Rauzier, J., Gicquel, B. \& Vincent, V. (1996). Mycobacterium xenopi IS1395, a novel insertion sequence expanding the IS256 family. Microbiology 142, 2453-2461.

Picardeau, M., Bull, T. J. \& Vincent, V. (1997). Identification and characterization of IS-like elements in Mycobacterium gordonae. FEMS Microbiol Lett 154, 95-102.

Sakaguchi, K. (1990). Invertrons, a class of structurally and functionally related genetic elements that includes linear DNA plasmids, transposable elements, and genomes of adeno-type viruses. Microbiol Rev 54, 66-74.

Sanger, F., Nicklen, S. \& Coulson, A. R. (1977). DNA sequencing with chain-terminating inhibitors. Proc Natl Acad Sci USA 74, 5463-5467.

Stackebrandt, E., Rainey, F. A. \& Ward-Rainey, N. L. (1997). Proposal for a new hierarchic classification system, Actinobacteria classis nov. Int J Syst Bacteriol 47, 479-491.

Wu, X. \& Roy, K. L. (1993). Complete nucleotide sequence of a linear plasmid from Streptomyces clavuligerus and characterization of its RNA transcripts. J Bacteriol 175, 37-52.

Zotchev, S. B., Soldatova, L. I., Orekhov, A. V. \& Schrempf, H. (1992). Characterization of a linear extrachromosomal DNA element (pBL1) isolated after interspecific mating between Streptomyces bambergiensis and S. lividans. Res Microbiol 143, 839-845.

Received 8 December 1997; revised 16 March 1998; accepted 1 April 1998. 